\title{
Evaluation of Quizalofop-Resistant Rice for Arkansas Rice Production Systems
}

\author{
Zachary D. Lancaster $\left[\mathbb{D}^{1}{ }^{1}\right.$ Jason K. Norsworthy, ${ }^{1}$ and Robert C. Scott ${ }^{2}$ \\ ${ }^{1}$ Department of Crop, Soil, and Environmental Sciences, University of Arkansas, Fayetteville, AR 72701, USA \\ ${ }^{2}$ Department of Crop, Soil, and Environmental Sciences, University of Arkansas, Lonoke, AR 72086, USA \\ Correspondence should be addressed to Zachary D. Lancaster; zdlancas@email.uark.edu
}

Received 9 January 2018; Revised 28 February 2018; Accepted 17 March 2018; Published 23 April 2018

Academic Editor: Rodomiro Ortiz

Copyright ( 2018 Zachary D. Lancaster et al. This is an open access article distributed under the Creative Commons Attribution License, which permits unrestricted use, distribution, and reproduction in any medium, provided the original work is properly cited.

\begin{abstract}
Due to the ongoing evolution of herbicide-resistant weeds, new technologies are needed to maintain effective levels of control. A new rice variety that will be resistant to quizalofop, an acetyl coenzyme A carboxylase- (ACCase-) inhibiting herbicide, is currently under development. With the anticipated launch of this technology in 2018, multiple experiments were conducted to determine effectiveness of the quizalofop-resistant rice system for common grass weed species found in Arkansas rice production. One hundred and twenty-six barnyardgrass populations were collected across Arkansas and treated with quizalofop at $80 \mathrm{~g}$ ai ha ${ }^{-1}$ to determine a baseline of response. All populations evaluated were effectively controlled ( $\geq 92 \%)$ by quizalofop, with only 13 populations resulting in lower than $98 \%$ control. A greenhouse and field trial were conducted to compare efficacy of quizalofop to currently labeled rice graminicides for control of common rice grass weeds. Results from the greenhouse experiment showed that quizalofop treatments resulted in greater efficacy of common grass weeds compared to cyhalofop or fenoxaprop. This was especially apparent at the larger grass growth stages. A field experiment conducted compared season-long weed control programs of quizalofop to fenoxaprop and cyhalofop. The quizalofop-containing treatments were no better than fenoxaprop and cyhalofop for barnyardgrass and broadleaf signalgrass control. Barnyardgrass and broadleaf signalgrass control were greater than $96 \%$ for all herbicide treatments. An additional field experiment was conducted to determine the best rate structure for sequential applications of quizalofop in rice. Sequential applications of quizalofop at $120 \mathrm{~g} \mathrm{ha}^{-1}$ followed by $120 \mathrm{~g} \mathrm{ha}^{-1}$ two weeks later resulted in the highest barnyardgrass and broadleaf signalgrass control. Likewise, applying the full seasonal use rate of $240 \mathrm{~g} \mathrm{ha}^{-1}$ of quizalofop resulted in greater control compared to 200 and $160 \mathrm{~g} \mathrm{ha}^{-1}$. Results from this research indicate a strong benefit from quizalofop use in rice.
\end{abstract}

\section{Introduction}

Arkansas is the top rice producing state, contributing over half of the United States rice production [1]. Rice production in Arkansas is generally located in the eastern half of the state, in the Mississippi River Delta region [2]. Weed control is a major obstacle for Arkansas rice production. Most of the rice grown is produced in a drill seeded, delayed flooding system, with only around $5 \%$ annually produced using a waterseeded system [3]. Hence, an effective weed control program in Arkansas begins with a preemergence residual herbicide followed by postemergence herbicide applications [4]. One of the main challenges to rice production is the ever increasing herbicide resistance found in multiple common rice weeds.
Two of the most problematic weeds to Arkansas rice production are barnyardgrass and red rice (Oryza sativa L.). While already difficult to control in rice, both of these species have evolved resistance to commonly used rice herbicides, making effective control even more difficult. Barnyardgrass is a principle rice weed globally, along with other closely related Echinochloa species, and thrives in the flooded rice production system [5]. Barnyardgrass has evolved resistance to many common rice herbicides, including propanil [6], quinclorac [7], and clomazone [8]. Red rice has long been difficult to control due to physiological similarities between it and commercial rice varieties [9]. Thus, to selectively control red rice as well as other common rice weeds, imidazolinone-resistant $\left(\right.$ Clearfield ${ }^{\mathrm{TM}}$ ) rice was commercially released in 2002 [10]. 
At its height of acceptance (2011), 64\% of planted rice in Arkansas and Mississippi was an imidazolinone-resistant variety [4]; however, the share of imidazolinone-resistant rice in Arkansas has declined in recent years to 44\% in 2015 [2]. The reduction in usage can partially be attributed to imidazolinone resistance in red rice [10] and barnyardgrass [11].

With the increased pressure herbicide-resistant weeds place on current rice production systems, a new technology is needed to achieve effective control of these weeds. The development of new herbicides quickly diminished with the launch of glyphosate-resistant crops in the 1990s. Although glyphosate-resistant weeds pushed the agrichemical industry to reinvest in herbicide discovery [12], no new herbicide mechanisms of action have been commercialized in recent years, leaving growers to work with a suite of herbicides that are less effective today because of widespread resistance [13]. To help combat herbicide-resistant rice weeds, a new herbicide-resistant rice technology (Provisia ${ }^{\mathrm{TM}}$ rice) is being developed. Provisia rice is resistant to quizalofop, an acetyl coenzyme A carboxylase- (ACCase-) inhibiting herbicide [14]. Quizalofop-resistant rice is a non-GMO crop and was developed using traditional plant breeding techniques to isolate the G2096S gene, which makes the acetyl coenzyme A carboxylase enzyme resistant to ACCase-inhibiting herbicides [15].

Quizalofop is a member of the aryloxyphenoxy propionate family and commonly used for effective control of annual weedy grasses and most perennial grass weeds [16]. Quizalofop, like other ACCase-inhibiting herbicides, only has activity on grass species, with broadleaf species having natural tolerance [17]. Quizalofop is currently labeled for use in multiple broadleaf crop and noncrop areas, where 35 to $84 \mathrm{~g}$ ai ha $^{-1}$ can be applied postemergence in soybean (Glycine $\max$ (L.) Merr.) and up to $112 \mathrm{~g} a i ~ h a^{-1}$ in noncrop areas [16]. The use rate for quizalofop in quizalofop-resistant rice will range from 100 to $138 \mathrm{~g} \mathrm{ai} \mathrm{ha}^{-1}$ for a single application and $240 \mathrm{~g}$ ai ha $^{-1}$ as a maximum yearly application [18]. Although quizalofop can provide moderate residual grass control [16], quizalofop will be restricted to only postemergence applications in quizalofop-resistant rice [19].

Herbicide resistance modeling has been used to predict that ACCase-inhibiting rice herbicides such as cyhalofop and fenoxaprop have a lower risk for resistance when compared to acetolactate synthase- (ALS-) inhibiting herbicides, such as those used in imidazolinone-resistant rice [20]. These findings support the hypothesis that quizalofop could be a successful selective herbicide in quizalofop-resistant rice if properly integrated with strategies to mitigate resistance. However, there are cases of grass weed species that have already evolved resistance to ACCase-inhibiting herbicides, including barnyardgrass in the Arkansas [21]. These instances of resistance can be attributed to both metabolic (non-target-site) and target-site resistance [22]. While no resistance to quizalofop has been confirmed in Arkansas, common rice weeds such as barnyardgrass (Mississippi), Amazon sprangletop (Leptochloa panicoides (J. Presl) A. S. Hitchc., Louisiana), and junglerice (Echinochloa colona (L.) Link, Arkansas) have been confirmed resistant to ACCase-inhibiting herbicides [21, 23].
Likewise, gene flow between a quizalofop-resistant rice variety and red rice could transfer herbicide resistance to red rice [10]. Although outcrossing percentage is low (0.109-0.434\%), this could result in several hundred resistant plants per hectare. Hence, proper stewardship of this technology is imperative for prolonged effectiveness.

Stewardship of this technology can be accomplished through yearly crop rotation. Crop rotation restriction will be unlikely with applications of quizalofop; however, quizalofopresistant rice cannot be planted after imidazolinone-resistant rice due to a lack of stacking of resistance traits to confer resistance to the imidazolinone herbicides [14]. With the commercialization of quizalofop-resistant rice in 2018, multiple experiments were conducted to determine the baseline response of Arkansas barnyardgrass populations to quizalofop as well as the efficacy of the quizalofop-resistant rice system compared to current grass weed control standards used in Arkansas rice production.

\section{Materials and Methods}

2.1. Barnyardgrass Accession Screening to Quizalofop. Barnyardgrass panicles were collected from 126 agricultural fields across the Mississippi delta region of Arkansas in the autumn of 2014. Populations were designated as B (barnyardgrass) and given a number value (1 to 126). Samples B1-B74 were personally collected with samples B75-B126 being sent in by University of Arkansas county extension agents. The number of panicles collected per accession was dependent on barnyardgrass density within a field. On average, 30 to 40 panicles were collected per accession. GPS coordinate and crop in the field at time of sampling were recorded. Populations were dried in the greenhouse (32/22 C) for 7 days, and then seeds were threshed from panicles and combined into single composite samples for each accession.

Approximately 50 seeds were sown into 8 by 14 by $5 \mathrm{~cm}$ pots containing a commercial potting mix (Professional Growing Mix, LC1 mix, Sun Gro Horticulture Distribution Inc., Bellevue, WA 98008). Pots were then placed in the greenhouse under conditions of 32/22 C day/night temperatures with a $16-\mathrm{h}$ photoperiod. The experiment was conducted as a randomized complete block design with four replications. Quizalofop (Targa ${ }^{\mathrm{TM}}$ herbicide, Gowan Company, Yuma, AZ) was applied at the 3- to 4-leaf growth stage at $80 \mathrm{~g}$ ai ha $^{-1}$ with $1 \% \mathrm{v} / \mathrm{v}$ crop oil concentrate (COC) (Agri-Dex, Helena Chemical Company, West Helena, AR 72390). Applications were made inside a stationary spray chamber calibrated to deliver $187 \mathrm{~L} \mathrm{ha}^{-1}$ at $276 \mathrm{kPA}$ with 800067 nozzles.

Visual barnyardgrass control assessments were taken at 14 and 21 days after treatment (DAT). Control was assessed on a scale of 0 to $100 \%$, where $0 \%$ was equivalent to no response and $100 \%$ was complete plant death compared to a nontreated check of each accession. Total emerged plants were counted for each tray. Mortality (\%) was calculated at 21 DAT. Alive plants were any plant with living tissue remaining after treatment. Due to collection method and greenhouse space constraints, only 45 populations were evaluated within one run. Within a run, 4 replications were included with 
nontreated checks for each accession. No formal analyses were conducted on individual runs to compare populations.

2.2. Efficacy of Quizalofop Compared to Currently Registered Rice Graminicides. A greenhouse and field experiment were conducted to compare the efficacy of quizalofop to currently registered rice graminicides. The greenhouse experiment was conducted in the autumn of 2014 and spring of 2015 at the University of Arkansas Research and Extension Center in Fayetteville, AR, to determine the effect of growth stage at application and choice of ACCase-inhibiting herbicide on control of common grass weeds found in Arkansas rice production systems. The experiment was conducted as a two-factor factorial, randomized complete block design (RCBD), with factor-A being growth stage of grass species at time of application and factor-B being ACCase-inhibiting herbicide treatment with four replications. Growth stages at application were 2- to 3-leaf, 5- to 6-leaf, and 12- to 16leaf grasses. Tested herbicides were quizalofop at 80, 120, and $160 \mathrm{~g}$ ai ha ${ }^{-1}$, fenoxaprop (Ricestar ${ }^{\circledR}$ HT herbicide, Bayer Crop Science LP, Research Triangle Park, NC) at $122 \mathrm{~g} \mathrm{ai} \mathrm{ha}^{-1}$, and cyhalofop (Clincher ${ }^{\circledR}$ SF herbicide, Dow AgroSciences LLC, Indianapolis, IN) at $313 \mathrm{gaiha}^{-1}$. A COC at $1 \% \mathrm{v} / \mathrm{v}$ was added to quizalofop and cyhalofop treatments. Tested weed species were barnyardgrass, broadleaf signalgrass, fall panicum (Panicum dichotomiflorum L.), and Amazon sprangletop. Approximately 20 seeds per 8 by 14 by $5 \mathrm{~cm}$ tray were sown into a commercial potting mix and watered daily under greenhouse conditions of $32 / 22 \mathrm{C}$ with a 16$\mathrm{h}$ photoperiod. After emergence, plants were thinned to 5 plants tray ${ }^{-1}$. Herbicide applications were similar to the previous experiment.

Visual assessment of control and plant biomass were collected similarly to the previous experiment. For data that met the assumptions for ANOVA, means were separated using Fisher's protected LSD $(\alpha=0.05)$. For data that did not meet the assumptions for ANOVA, only treatment means are presented. Few differences were observed between 14 and 21 DAT control ratings; thus only the 21 DAT rating will be presented.

A field experiment was conducted in 2014 and 2015 to determine the efficacy of quizalofop compared to other ACCase-inhibiting rice herbicides with and without clomazone preemergence in quizalofop-resistant rice. The experiment was located at the Pine Tree Research Station near Colt, AR, on a Calloway silt-loam soil (Fine-Silty, mixed, active, thermic Aquic Fraglossudalfs). An experimental quizalofopresistant rice variety (Provisia rice, BASF Corp., Research Triangle Park, NC) was planted on May 2, 2014, and April 30, 2015 , at a seeding rate of 67 seeds $\mathrm{m}^{-1}$ row. Plots consisted of 9 drill seeded rows on $18 \mathrm{~cm}$ centers, $7.6 \mathrm{~m}$ long.

The experimental design was a RCB factorial with four replications and three factors: presence or absence of clomazone preemergence, sequential application of quizalofop versus fenoxaprop followed by cyhalofop, and timing of the sequential herbicide application. Plots either had clomazone (Command $^{\mathrm{TM}}$ herbicide, FMC Corporation, Philadelphia, $\mathrm{PA}$ ) applied at $336 \mathrm{~g} \mathrm{ai} \mathrm{ha}^{-1}$ preemergence or no preemergence herbicide. Herbicide regimes consisted of either sequential applications of quizalofop at $120 \mathrm{~g} \mathrm{ha}^{-1}$ each or a sequential application of fenoxaprop at $122 \mathrm{~g} \mathrm{ha}^{-1}$ followed by cyhalofop at $313 \mathrm{~g} \mathrm{ha}^{-1}$. The initial postemergence application was always made at the 3- to 4-leaf stage of rice, whereas the sequential application was either made before flood or 2 weeks after flood. Herbicide treatments were applied using a $\mathrm{CO}_{2}$-backpack sprayer calibrated to deliver $143 \mathrm{~L} \mathrm{ha}^{-1}$ at $276 \mathrm{kPA}$ with XR110015 nozzles. All quizalofop and cyhalofop treatments included a COC at $1 \% \mathrm{v} / \mathrm{v}$. Broadleaf weeds and sedges were controlled by overspraying the entire test with 2,4-D at $533 \mathrm{~g} \mathrm{ae} \mathrm{ha}^{-1}$ (Weedar ${ }^{\mathrm{TM}}$ herbicide, Nufarm Americas INC, Alsip, IL) and halosulfuron at $21 \mathrm{~g} \mathrm{ai} \mathrm{ha}^{-1}$ (Permit $^{\circledR}$ herbicide, Gowan Company LLC, Yuma, AZ).

Visual weed control and crop injury were assessed as previously noted. Ratings for control of a natural population of barnyardgrass and broadleaf signalgrass were taken 14 and 21 days after each herbicide application in both 2014 and 2015. Stand counts of emerged rice seedlings per meter row were taken at 14 days after planting. The experiment was terminated before the rice reached panicle exertion because a nonregistered rice variety was planted. Before termination weed biomass of barnyardgrass and broadleaf signalgrass per $\mathrm{m}^{2}$ was taken, biomass samples were weighed after being oven-dried at $65 \mathrm{C}$ for two weeks. Data for this experiment were analyzed using the Fit Model procedure in JMP Pro 12.1. Year and replication nested within years were considered random effects. No parameters for this experiment resulted in significant interactions or main effects; hence, only treatment means are presented.

\subsection{Best Rate Structure for Sequential Applications of Quizalo-} fop in Quizalofop-Resistant Rice. An experiment was conducted to determine the best rate structure of sequential applications of quizalofop to quizalofop-resistant rice, when applied initially to either 2- or 6-leaf grasses. The field experiment was conducted in 2014 and 2015 on a Dewitt silt-loam soil (Fine, smectitic, thermic Typic Albaqualfs) at the Rice Research and Extension Center near Stuttgart, AR. The experiment was conducted as a two-factor RCBD with factor-A being growth stage of grass weeds at time of first application and factor-B being quizalofop rate structure with four replications. An experimental quizalofop-resistant rice variety was planted on 18 -cm width rows, in 1.8 by $6.1 \mathrm{~m}$ plots, at a rate of 67 seeds $\mathrm{m}^{-1}$ row. Planting occurred on April 26, 2014, and April 21, 2015. Quizalofop applications were applied to a natural population of grasses, with no preemergence herbicide applied to insure a high weed density. Quizalofop was applied as previously noted with broadleaf weeds and sedges controlled in a similar manner to the previous experiment. The quizalofop rate structure was 80,120 , or $160 \mathrm{~g} \mathrm{ha}^{-1}$ followed by a sequential application of 80,120 , or $160 \mathrm{~g} \mathrm{ha}^{-1}$. All rate combinations evaluated did not exceed the maximum yearly application rate of $240 \mathrm{~g} \mathrm{ha}^{-1}$ to be applied over both combinations. For instance, quizalofop at $160 \mathrm{~g} \mathrm{ha}^{-1}$ followed by $120 \mathrm{~g} \mathrm{ha}^{-1}$ was not evaluated because this treatment would have exceeded the allowable yearly maximum [18].

Visual estimates of weed control and crop injury were rated. Barnyardgrass and broadleaf signalgrass control were 
TABLE 1: Effect of ACCase-inhibiting herbicide and growth stage at time of application for control of barnyardgrass, broadleaf signalgrass, fall panicum, and Amazon sprangletop at $21 \mathrm{DAT}^{\mathrm{a}}$

\begin{tabular}{|c|c|c|c|c|c|c|}
\hline \multirow{3}{*}{ Growth stage } & \multirow{3}{*}{ Herbicide } & \multirow{3}{*}{$\begin{array}{c}\text { Rate } \\
\text { g ai ha }^{-1}\end{array}$} & \multicolumn{4}{|c|}{ Control $^{\mathrm{b}}$} \\
\hline & & & ECHCG & BRAPP & PANDI & LEFPA \\
\hline & & & \multicolumn{4}{|c|}{$\%$} \\
\hline \multirow{5}{*}{ 2- to 3-leaf } & Quizalofop & 80 & $100 \mathrm{a}$ & $99 \mathrm{a}$ & $100 \mathrm{a}$ & $100 \mathrm{a}$ \\
\hline & Quizalofop & 120 & $100 \mathrm{a}$ & $100 \mathrm{a}$ & $100 \mathrm{a}$ & $100 \mathrm{a}$ \\
\hline & Quizalofop & 160 & $100 \mathrm{a}$ & $100 \mathrm{a}$ & $100 \mathrm{a}$ & $100 \mathrm{a}$ \\
\hline & Fenoxaprop & 122 & $96 \mathrm{ab}$ & $99 \mathrm{a}$ & $100 \mathrm{a}$ & 99 a \\
\hline & Cyhalofop & 313 & $96 \mathrm{ab}$ & $98 \mathrm{a}$ & $100 \mathrm{a}$ & $98 \mathrm{ab}$ \\
\hline \multirow{5}{*}{ 5- to 6-leaf } & Quizalofop & 80 & $91 \mathrm{bc}$ & $100 \mathrm{a}$ & $99 a$ & $96 \mathrm{~b}$ \\
\hline & Quizalofop & 120 & $97 \mathrm{a}$ & $100 \mathrm{a}$ & $100 \mathrm{a}$ & $100 \mathrm{a}$ \\
\hline & Quizalofop & 160 & $99 \mathrm{a}$ & $100 \mathrm{a}$ & $100 \mathrm{a}$ & $100 \mathrm{a}$ \\
\hline & Fenoxaprop & 122 & $89 c$ & $85 \mathrm{~b}$ & $76 c$ & $85 c$ \\
\hline & Cyhalofop & 313 & $48 \mathrm{~d}$ & $56 \mathrm{~d}$ & $39 \mathrm{~d}$ & $44 \mathrm{~g}$ \\
\hline \multirow{5}{*}{ 12- to 16-leaf } & Quizalofop & 80 & $36 \mathrm{e}$ & $54 \mathrm{~d}$ & $92 \mathrm{~b}$ & $70 \mathrm{e}$ \\
\hline & Quizalofop & 120 & $40 \mathrm{e}$ & $64 c$ & $90 \mathrm{~b}$ & $73 \mathrm{e}$ \\
\hline & Quizalofop & 160 & $53 \mathrm{~d}$ & $86 \mathrm{~b}$ & $95 \mathrm{ab}$ & $80 \mathrm{~d}$ \\
\hline & Fenoxaprop & 122 & $27 \mathrm{f}$ & $33 \mathrm{f}$ & $75 c$ & $61 \mathrm{f}$ \\
\hline & Cyhalofop & 313 & $19 \mathrm{~g}$ & $47 \mathrm{e}$ & $29 \mathrm{e}$ & $38 \mathrm{~h}$ \\
\hline
\end{tabular}

${ }^{a}$ DAT: days after treatment, ECHCG: barnyardgrass, BRAPP: broadleaf signalgrass, PANDI: fall panicum, LEFPA: Amazon sprangletop. ${ }^{\mathrm{b}}$ Means within a column followed by the same letter are not different according to Fisher's LSD $(\alpha=0.05)$.

evaluated in 2014 and 2015 along with red rice in 2015. Rice plant heights were taken multiple times throughout the experiment for both 2014 and 2015. No grain yield were collected due to crop termination before crop maturity. Data for this experiment were analyzed using the Fit Model procedure in JMP Pro 12.1. For data that met assumptions for ANOVA, means were separated using Fisher's protected LSD $(\alpha=0.05)$ and preplanned contrasts were conducted for select treatments to compare between total yearly amounts of quizalofop applied $(\alpha=0.05)$. Years were analyzed and will be presented separately for 2014 and 2015.

\section{Results and Discussion}

3.1. Barnyardgrass Population Screening. Overall, quizalofop at $80 \mathrm{gai} \mathrm{ha}^{-1}$ was effective for controlling the populations tested. At 21 DAT, barnyardgrass control across populations was $99 \%$ (data not shown). Of the 126 populations evaluated, 113 were completely controlled by quizalofop (100\%), with no living tissue remaining at 21 DAT. For the 13 populations that were not completely controlled, quizalofop achieved at least $92 \%$ control (data not shown). In these 13 populations, the lowest mortality was only $80 \%$ with accession B91. Even with an $80 \%$ mortality rate, live plants only had a small portion of living tissue and most likely would not have been competitive in a field setting. Although ACCase-resistant barnyardgrass has been confirmed in the Mid-South (21), all populations evaluated were adequately controlled with quizalofop. With use rates being 100 to $138 \mathrm{~g} \mathrm{ha}^{-1}$ for a single application [18], quizalofop is expected to be an effective herbicide to control barnyardgrass in rice.
3.2. Efficacy of Quizalofop Compared to Registered Rice Graminicides: Greenhouse Experiment. A significant growth stage by herbicide interaction was observed for visual control and biomass for all grass species. ACCase-inhibiting herbicides were effective for controlling all species evaluated the 2 - to 3-leaf growth stage ( $>96 \%$ ) (Table 1), with no significant difference between treatments. Likewise, no difference was observed between herbicides for relative biomass at the 2- to 3-leaf timing of any grass species (Table 2). For applications to larger grass, there did appear to be differences in efficacy among the herbicides evaluated. At the 5- to 6-leaf and 12 - to 16-leaf growth stages, quizalofop across rates consistently provided greater control compared to fenoxaprop and cyhalofop (Table 1). Only the lowest rate of quizalofop (91\%) was similar to fenoxaprop (89\%) for control of 5- to 6-leaf barnyardgrass. Quizalofop, regardless of rate, provided a high level of control (>90\%) for all grass species at the 5- to 6-leaf growth stage. Similarly, broadleaf signalgrass, fall panicum, and Amazon sprangletop treated at the 5- to 6-leaf stage usually had less biomass following quizalofop treatments compared to fenoxaprop and cyhalofop (Table 2).

Control drastically decreased for all graminicides applied to 12- to 16-leaf grasses (Table 1). For barnyardgrass, control from the high rate of quizalofop was reduced from $99 \%$ at the 5- to 6-leaf growth stage to only $53 \%$ at the 12 - to 16 leaf stage (Table 1) while relative biomass increased from 6 to $55 \%$ (Table 2). Likewise, these herbicides were not effective for controlling broadleaf signalgrass at the largest growth stage (33 to $64 \%$ control), except for the high rate of quizalofop (86\%). Fall panicum was still highly susceptible to quizalofop at the 12- to 16-leaf growth stage, with all quizalofop 
TABLE 2: Effect of ACCase-inhibiting herbicide and growth stage at time of application on relative biomass of barnyardgrass, broadleaf signalgrass, fall panicum, and Amazon sprangletop at $21 \mathrm{DAT}^{\mathrm{a}}$

\begin{tabular}{|c|c|c|c|c|c|c|}
\hline \multirow{3}{*}{ Grass size } & \multirow{3}{*}{ Herbicide } & \multirow{3}{*}{$\begin{array}{c}\text { Rate } \\
\text { g ai ha }\end{array}$} & \multicolumn{4}{|c|}{ Biomass $^{b c}$} \\
\hline & & & ECHCG & BRAPP & PANDI & LEFPA \\
\hline & & & \multicolumn{4}{|c|}{$\%$ of untreated check } \\
\hline \multirow{5}{*}{ 2- to 3-leaf } & Quizalofop & 80 & $5 \mathrm{e}$ & $7 \mathrm{e}$ & $4 \mathrm{~d}$ & $4 \mathrm{f}$ \\
\hline & Quizalofop & 120 & $7 \mathrm{e}$ & $6 \mathrm{e}$ & $3 \mathrm{~d}$ & $3 \mathrm{f}$ \\
\hline & Quizalofop & 160 & $5 \mathrm{e}$ & $4 \mathrm{e}$ & $3 \mathrm{~d}$ & $3 \mathrm{f}$ \\
\hline & Fenoxaprop & 122 & $8 \mathrm{e}$ & $6 \mathrm{e}$ & $4 \mathrm{~d}$ & $5 \mathrm{f}$ \\
\hline & Cyhalofop & 313 & $8 \mathrm{e}$ & $7 \mathrm{e}$ & $6 \mathrm{~d}$ & $4 \mathrm{f}$ \\
\hline \multirow{5}{*}{ 5- to 6-leaf } & Quizalofop & 80 & $7 \mathrm{e}$ & $8 \mathrm{e}$ & $4 \mathrm{~d}$ & 7 ef \\
\hline & Quizalofop & 120 & $8 \mathrm{e}$ & $7 \mathrm{e}$ & $5 \mathrm{~d}$ & $5 \mathrm{f}$ \\
\hline & Quizalofop & 160 & $6 \mathrm{e}$ & $7 \mathrm{e}$ & $4 \mathrm{~d}$ & $4 \mathrm{f}$ \\
\hline & Fenoxaprop & 122 & $9 \mathrm{e}$ & $20 \mathrm{~d}$ & $20 \mathrm{c}$ & $16 \mathrm{de}$ \\
\hline & Cyhalofop & 313 & $43 \mathrm{~d}$ & $41 \mathrm{c}$ & $63 \mathrm{a}$ & $60 \mathrm{a}$ \\
\hline \multirow{5}{*}{12 - to 16 -leaf } & Quizalofop & 80 & $61 \mathrm{bc}$ & $57 \mathrm{ab}$ & $20 \mathrm{c}$ & $27 c$ \\
\hline & Quizalofop & 120 & $58 \mathrm{c}$ & $51 \mathrm{bc}$ & $19 \mathrm{c}$ & $27 c$ \\
\hline & Quizalofop & 160 & $55 \mathrm{c}$ & $22 \mathrm{~d}$ & $18 \mathrm{c}$ & $22 \mathrm{~cd}$ \\
\hline & Fenoxaprop & 122 & $67 \mathrm{~b}$ & $65 \mathrm{a}$ & $39 \mathrm{~b}$ & $44 \mathrm{~b}$ \\
\hline & Cyhalofop & 313 & $84 \mathrm{a}$ & $62 \mathrm{ab}$ & $69 \mathrm{a}$ & $67 \mathrm{a}$ \\
\hline
\end{tabular}

${ }^{a}$ DAT: days after treatment, ECHCG: barnyardgrass, BRAPP: broadleaf signalgrass, PANDI: fall panicum, LEFPA: Amazon sprangletop. ${ }^{\mathrm{b}}$ Means within a column followed by the same letter are not different according to Fisher's protected LSD $(\alpha=0.05)$. ${ }^{\mathrm{c}}$ Data expressed as percent relative biomass compared with nontreated control for each grass species and growth stage. Nontreated check was harvested on the same day as treated plots.

treatments producing $>90 \%$ control (Table 1 ) with $\leq 20 \%$ biomass relative to the untreated control (Table 2). Overall, at the rates tested, quizalofop appears to have greater grass activity than either fenoxaprop or cyhalofop, which is similar to previous experiments which have often shown quizalofop to outperform other ACCase-inhibiting herbicides [24-26]. Moreover, quizalofop remained more effective on the grass weeds evaluated at larger growth stages (5- to 6-leaf, 12- to 16-leaf), whereas fenoxaprop and cyhalofop efficacy quickly diminished.

3.3. Field Experiment. Overall, no parameter evaluated for this experiment produced a significant interaction or main effect for either 2014 or 2015. Grass weeds were effectively controlled by all treatments, with all control ratings for both barnyardgrass and broadleaf signalgrass being $>96 \%$ (data not shown). At 21 days after the sequential application, barnyardgrass and broadleaf signalgrass control ranged from 97 to $99 \%$ for all treatments. Presence or absence of clomazone preemergence did not affect the emergence of rice, with no significant difference between rice stand counts at 14 days after planting (data not shown). The experimental quizalofop-resistant rice variety showed no symptoms of injury from any ACCase-inhibiting herbicide applied. Visual injury ratings taken 14 and 21 days after graminicide application were never higher than $5 \%$ for any treatment, with injury symptoms being small chlorotic spotting consistent with injury caused from the adjuvant. Only nontreated check plots had grass weeds present at the time of test termination; thus they were the only plots in which weed biomass were harvested. Nontreated checks resulted in 43.2 and $28.7 \mathrm{~g} \mathrm{~m}^{-2}$ oven-dried biomass averaged over both years for barnyardgrass and broadleaf signalgrass, respectively.

Averaged over both years, density of barnyardgrass and broadleaf signalgrass was only 4.2 and 3.6 plants $\mathrm{m}^{-2}$, respectively, at time of the initial postemergence application (3to 4-leaf rice). Previous research has shown that as weed density decreases, efficacy of herbicides can increase. This is especially true with ACCase-inhibiting herbicides, where Ndou (2009) [27] found that as large crabgrass (Digitaria sanguinalis (L.) Scop.) density decreased, percent mortality with clethodim increased.

3.4. Best Rate Structure for Sequential Applications of Quizalofop in Quizalofop-Resistant Rice. In 2014, there was not a significant interaction of quizalofop rate structure by growth stage; however, there were significant main effects of rate structure and growth stage for both barnyardgrass and broadleaf signalgrass control. At 21 days after the sequential application, the $120 \mathrm{fb} 120 \mathrm{~g} \mathrm{ha}^{-1}$ rate structure controlled barnyardgrass $98 \%$ but was only significantly different from the $80 \mathrm{fb} 80 \mathrm{~g} \mathrm{ha}^{-1}$ structure which produced $89 \%$ control (Table 3). Similarly, the highest control of broadleaf

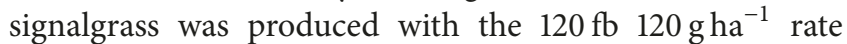
structure but again was only significantly different from the $80 \mathrm{fb} 80 \mathrm{~g} \mathrm{ha}^{-1}$ rate structure which resulted in $91 \%$ control. Based on an orthogonal contrast, using the full seasonal quizalofop use rate of $240 \mathrm{~g} \mathrm{ha}^{-1}$ significantly increased both barnyardgrass and broadleaf signalgrass control compared to seasonal use rates of 200 and $160 \mathrm{~g} \mathrm{ha}^{-1}$. When the initial application of quizalofop was made at the 2-leaf growth stage it resulted in $98 \%$ control of barnyardgrass, averaged over 
TABLE 3: Effect of quizalofop application structure on barnyardgrass, broadleaf signalgrass, and red rice control at Stuttgart, AR, in 2014 and 2015 averaged over time of first application followed by contrast between total quizalofop usage rates.

\begin{tabular}{|c|c|c|c|c|c|}
\hline \multirow{4}{*}{$\begin{array}{l}\text { Application structure }^{\mathrm{a}} \\
\mathrm{g} \mathrm{ai} \mathrm{ha}^{-1}\end{array}$} & \multicolumn{5}{|c|}{ Control $^{\mathrm{b}}$} \\
\hline & \multicolumn{2}{|c|}{$2014^{c}$} & \multicolumn{3}{|c|}{$2015^{\mathrm{d}}$} \\
\hline & ECHCG & BRAPP & ECHCG & BRAPP & ORYSA \\
\hline & & & $\%$ & & \\
\hline $80 / 80$ & $89 \mathrm{~b}$ & $91 \mathrm{~b}$ & $94 \mathrm{a}$ & $97 \mathrm{a}$ & $95 \mathrm{a}$ \\
\hline $80 / 120$ & $90 \mathrm{ab}$ & $95 \mathrm{ab}$ & $96 a$ & $98 \mathrm{a}$ & $99 \mathrm{a}$ \\
\hline $80 / 160$ & $91 \mathrm{ab}$ & $98 \mathrm{a}$ & $97 a$ & $100 \mathrm{a}$ & $98 \mathrm{a}$ \\
\hline $120 / 80$ & $91 \mathrm{ab}$ & $96 \mathrm{ab}$ & $94 a$ & $99 a$ & $98 \mathrm{a}$ \\
\hline $120 / 120$ & $98 \mathrm{a}$ & 99 a & $98 \mathrm{a}$ & $100 \mathrm{a}$ & $99 a$ \\
\hline $160 / 80$ & $95 \mathrm{a}$ & $98 \mathrm{a}$ & $98 \mathrm{a}$ & $100 \mathrm{a}$ & $98 \mathrm{a}$ \\
\hline \multicolumn{6}{|l|}{$\begin{array}{l}\text { Contrast }^{\mathrm{e}} \\
\mathrm{g} \mathrm{ai} \mathrm{ha}^{-1}\end{array}$} \\
\hline 240 vs. 160 & $<0.0001$ & 0.0032 & 0.0415 & NS & 0.0150 \\
\hline 240 vs. 200 & 0.0049 & 0.0311 & NS & NS & NS \\
\hline 200 vs. 160 & 0.0246 & 0.0099 & NS & NS & NS \\
\hline
\end{tabular}

${ }^{a}$ First rate applied followed by (/) second rate applied 2 weeks later. ${ }^{b}$ ECHCG: barnyardgrass, BRAPP: broadleaf signalgrass, ORYSA: red rice. ${ }^{\mathrm{c}}$ Means within a column followed by the same letter are not different according to Fisher's protected LSD $(\alpha=0.05)$. ${ }^{\mathrm{d}} 2015$ resulted in no significant difference between quizalofop application structure for any weed species. ${ }^{\mathrm{e}}$ Total yearly amount of quizalofop applied.

TABLE 4: Effect of grass growth stage at time of first quizalofop application on barnyardgrass, broadleaf signalgrass, and red rice control in 2014 and 2015 at Stuttgart, AR.

\begin{tabular}{|c|c|c|c|c|c|}
\hline \multirow{3}{*}{ Growth stage ${ }^{b}$} & \multicolumn{5}{|c|}{ Control $^{\mathrm{a}, \mathrm{c}}$} \\
\hline & \multicolumn{2}{|c|}{2014} & \multicolumn{3}{|c|}{2015} \\
\hline & ECHCG & BRAPP & ECHCG & BRAPP $^{d}$ & ORYSA \\
\hline 2-leaf & $98 \mathrm{a}$ & $98 \mathrm{a}$ & $98 \mathrm{a}$ & $98 \mathrm{a}$ & $99 \mathrm{a}$ \\
\hline 6-leaf & $87 \mathrm{~b}$ & $95 \mathrm{~b}$ & $93 \mathrm{~b}$ & $97 a$ & $97 \mathrm{~b}$ \\
\hline
\end{tabular}

${ }^{\mathrm{a}}$ ECHCG: barnyardgrass, BRAPP: broadleaf signalgrass, ORYSA: red rice. ${ }^{\mathrm{b}}$ Growth stage of grasses at the first application of quizalofop with a subsequent applications 14 days later. ${ }^{\mathrm{c}}$ Means within a column followed by the same letter are not different according to Fisher's protected LSD $(\alpha=0.05)$. ${ }^{\mathrm{d}} 2015$ resulted in no significant difference between growth stage at initial application for broadleaf signalgrass $(\alpha=0.05)$.

rates; however, when the application occurred at the 6-leaf growth stage, control declined to $87 \%$ (Table 4). The same trend was apparent for broadleaf signalgrass as well, where when initially applied at the 2-leaf growth stage, control averaged $98 \%$ over rate structure, but when initiated at the 6-leaf growth stage, control declined to $95 \%$.

In 2015, the experiment contained red rice in addition to barnyardgrass and broadleaf signalgrass. The overall weed density was less in 2015 , which may have contributed to differing results between years. No significant difference was observed in quizalofop rate structure for barnyardgrass, broadleaf signalgrass, or red rice. Control of barnyardgrass, broadleaf signalgrass, and red rice ranged from 94 to $98 \%$, 97 to $100 \%$, and 95 to $99 \%$, respectively, at 21 days after sequential application (Table 4). Based on a preplanned contrast, there was a difference in full seasonal quizalofop use rate $\left(240 \mathrm{~g} \mathrm{ha}^{-1}\right)$ compared to the low seasonal use rate $\left(160 \mathrm{~g} \mathrm{ha}^{-1}\right)$ for barnyardgrass and red rice control. Likewise, there was a main effect of growth stage of initial application for barnyardgrass and red rice control. When the initial application of quizalofop was made at the 2-leaf growth stage, barnyardgrass grass control was $98 \%$; however, when it was initiated at the 6-leaf growth stage, control decreased to $93 \%$ (Table 4). Similarly, red rice control was $99 \%$ when applied at the 2-leaf growth stage but was reduced to $97 \%$ when the first application was to 6-leaf plants. Although this seems like a small difference, due the potential for gene flow from quizalofop-resistant rice to red rice, even a few escapes of red rice within a field can lead to the rapid evolution of resistance [28].

Results from this experiment support applications of quizalofop in quizalofop-resistant rice as an effective option for controlling annual grass weed species. Moreover, the results support the current labeled single application rates of quizalofop at 100 to $138 \mathrm{~g} \mathrm{ha}^{-1}$ as well as the total seasonal use rate of $240 \mathrm{~g} \mathrm{ha}^{-1}$ [18].

\section{Conclusions}

Quizalofop-resistant rice can be an effective weed control technology for annual grass control in Arkansas rice production systems. Quizalofop alone effectively controlled all 126 barnyardgrass populations from across the state of Arkansas, even at a lower than labeled rate $\left(80 \mathrm{gha}^{-1}\right)$ for quizalofopresistant rice. However, there have already been cases of ACCase-resistant grass weed species within the Mid-South. 
To reduce the risk of resistance development, following a strict crop rotation plan is the best for producers. It is currently suggested to grow quizalofop-resistant rice once every 3 years in conjunction with imidazolinone-resistant rice and soybean [19]. This approach would limit the amount of quizalofop and would allow for the use of multiple herbicide modes of action for control of annual grass species.

Quizalofop also generally outperformed other currently labeled rice graminicides, especially on larger grasses. Over multiple years and locations, quizalofop-resistant rice exhibited high levels of tolerance to quizalofop ( $<5 \%$ injury), meaning the likelihood for injury to commercial cultivars from the herbicide should be low. For optimum efficacy, employing sequential applications is the best that can be done, where the first application targets two-leaf or smaller grasses using the full seasonal rate of $240 \mathrm{~g} \mathrm{ha}^{-1}$. Delaying applications or reducing the use rate would likely increase the risk for resistance in barnyardgrass and gene flow from red rice. Extra precautions will need to be taken in respect to control of red rice due to the risk of gene flow through cross-pollination of quizalofop-resistant rice with red rice [29]; these can include managing red rice on field borders, minimizing carryover of weed seed-bank to the following crop, and using clean crop seed (certified seed) [18]. Within the full seasonal quizalofop use rate, sequential applications of $120 \mathrm{~g} \mathrm{ha}^{-1}$ followed by $120 \mathrm{~g} \mathrm{ha}^{-1}$ performed best for the grass weeds evaluated.

\section{Conflicts of Interest}

The authors declare that there are no conflicts of interest regarding the publication of this paper.

\section{Acknowledgments}

Funding for this research was provided by the Arkansas Rice Research and Promotion Board. This publication is part of a thesis titled "Evaluation of Provisia Rice for Arkansas Rice Production Systems" by Zachary Lancaster for fulfillment of a degree from the University of Arkansas.

\section{References}

[1] [NASS] National Agricultural Statistics Service, "Arkansas acreage report 2016," https://www.nass.usda.gov/Statistics_by_ State/Arkansas/Publications/Crop_Releases/Acreage/2016/aracreage16.pdf.

[2] J. T. Hardke, B.R. Wells Arkansas Rice Research Studies 2015, R. J. Norman and K. A. K. Moldenhauer, Eds., University of Arkansas Agricultural Experiment Station Research Series, Fayetteville, NC, USA, 2016.

[3] J. T. Hardke, Arkansas Rice Production Handbook. Arkansas Cooperative Extension Service Miscellaneous Publications, vol. 129, University of Arkansas, Little Rock, AR, USA, 2012.

[4] J. K. Norsworthy, J. Bond, and R. C. Scott, "Weed management practices and needs in Arkansas and Mississippi rice," Weed Technology, vol. 27, no. 3, pp. 623-630, 2013.

[5] L. G. Holm, J. V. Pancho, J. P. Herberger, and D. L. Plucknett, The Worlds Worst Weeds, University Press of Hawaii, Honolulu, HI, USA, 1977.
[6] V. F. Carey, R. E. Hoagland, and R. E. Talbert, "Verification and distribution of propanil-resistant barnyardgrass (Echinochloa crus-galli) in Arkansas," Weed Technology, vol. 9, no. 2, pp. 366372, 1995.

[7] M. L. Lovelace, R. E. Talbert, R. E. Hoagland, and E. F. Scherder, "Quinclorac absorption and translocation characteristics in quinclorac- and propanil-resistant and -susceptible barnyardgrass (Echinochloa crus-galli) biotypes," Weed Technology, vol. 21, no. 3, pp. 683-687, 2007.

[8] J. K. Norsworthy, R. C. Scott, and K. L. Smith, B.R. Wells Arkansas Rice Research Studies, R. J. Norman, K. A. K. Moldenhauer, and B. R. Wells, Eds., vol. 560 of University of Arkansas Agriculture Experiment Station Research Series, Fayetteville, NC, USA, 2007.

[9] F. L. Baldwin, B. A. Huey, and G. L. Morris, "Distribution of three weed species in Arkansas rice fields," in Proceedings of the Southern Weed Science Society, vol. 30, p. 398, 1977.

[10] N. R. Burgos, J. K. Norsworthy, R. C. Scott, and K. L. Smith, "Red rice (Oryza sativa) status after 5 years of imidazolinone-resistant rice technology in Arkansas," Weed Technology, vol. 22, no. 1, pp. 200-208, 2008.

[11] D. S. Riar, J. K. Norsworthy, J. A. Bond, M. T. Bararpour, M. J. Wilson, and R. C. Scott, "Resistance of " International Journal of Agronomy, vol. 2012, pp. 1-8, 2012.

[12] S. O. Duke, "Why have no new herbicide modes of action appeared in recent years?" Pest Management Science, vol. 68, no. 4, pp. 505-512, 2012.

[13] R. E. Talbert and N. R. Burgos, "History and management of herbicide-resistant barnyardgrass (Echinochloa crus-galli) in Arkansas rice," Weed Technology, vol. 21, no. 2, pp. 324-331, 2007.

[14] J. Guice, C. Youman, A. Rhodes et al., "Provisia ${ }^{\mathrm{TM}}$ rice system; weed management strategies for rice," in Proceedings of Southern Weed Science Society the annual meeting, vol. 197, Southern Weed Science Society, Savanna, GA, USA, 2015.

[15] M. Hinga, S. Griffin, M. S. Moon, R. D. Rasmussen, and F. Cuevas, Methods and compositions to produce rice resistant to ACCase inhibitors, US patent 20130023416 A1, 2013.

[16] DL. Shaner, Herbicide Handbook, DL. Shaner, Ed., Weed Science Society of America, Lawrence, Mass, USA, 10th edition, 2014.

[17] T. Konishi and Y. Sasaki, "Compartmentalization of two forms of acetyl-CoA carboxylase in plants and the origin of their tolerance toward herbicides," Proceedings of the National Acadamy of Sciences of the United States of America, vol. 91, no. 9, pp. 35983601, 1994.

[18] Anonymous, "Provisia ${ }^{\mathrm{TM}}$ herbicide product label," in NVA 201704-522-0004, Research Triangle Park, NC. BASF Corporation, 2017.

[19] C. Youman, J. Guice, A. Rhodes, A. Schultz, and J. Harden, "Provisia rice production system efficacy and stewardship," in Proceedings of the in Proceedings of the Southern Weed Science Society annual conference, vol. 278, San Juan, PR, 2016.

[20] M. V. Bagavathiannan, J. K. Norsworthy, K. L. Smith, and P. Neve, "Modeling the simultaneous evolution of resistance to ALS-and ACCase-inhibiting herbicides in barnyardgrass (Echinochloa crus-galli) in Clearfield ${ }^{\circledR}$ rice," Weed Technology, vol. 28, no. 1, pp. 89-103, 2014.

[21] I. Heap, "Trends in the development of herbicide-resistant weeds," in Integrated weed management for sustainable agriculture, Burleigh Dodds Series in Agricultural Science, Burleigh Dodds Science Publishing, 2017. 
[22] S. S. Kaundun, "Resistance to acetyl-CoA carboxylaseinhibiting herbicides," Pest Management Science, vol. 70, no. 9, pp. 1405-1417, 2014.

[23] C. E. Rouse, N. Burgos, A. Lawton-Rauh, and R. A. Salas, "Herbicide resistance mechanisms of multiple resistant junglerice (Echinochloa colona) from Arkansas," in Proceedings of the in Proceedings of the Southern Weed Science Society annual conference, San Juan, PR, USA, 2016.

[24] R. E. Blackshaw, K. N. Harker, G. W. Clayton, and J. T. O'Donovan, "Broadleaf herbicide effects on clethodim and quizalofop-P efficacy on volunteer wheat (Triticum aestivum)," Weed Technology, vol. 20, no. 1, pp. 221-226, 2006.

[25] W. Deen, A. Hamill, C. Shropshire, N. Soltani, and P. H. Sikkema, "Control of volunteer glyphosate-resistant corn (Lea mays) in glyphosate-resistant soybean (Glycine max)," Weed Technology, vol. 20, no. 1, pp. 261-266, 2006.

[26] B. W. Minton, D. R. Shaw, and M. E. Kurtz, "Postemergence Grass and Broadleaf Herbicide Interactions for Red Rice (Oryza sativa) Control in Soybeans (Glycine max)," Weed Technology, vol. 3, no. 2, pp. 329-334, 1989.

[27] A. M. Ndou, Interaction of weed emergence, weed density, and herbicide rate in soybean [Ph.D. thesis], Kansas State University, Manhattan, 2009.

[28] D. H. Gealy, H. Agrama, and M. H. Jia, "Genetic analysis of atypical U.S. red rice phenotypes: Indications of prior gene flow in rice fields?" Weed Science, vol. 60, no. 3, pp. 451-461, 2012.

[29] V. K. Shivrain, N. R. Burgos, M. A. Sales et al., "Factors affecting the outcrossing rate between clearfield ${ }^{\mathrm{TM}}$ rice and red rice (oryza sativa)," Weed Science, vol. 57, no. 4, pp. 394-403, 2009. 


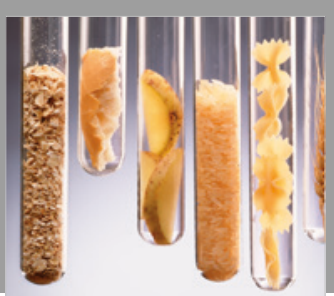

International Journal of Food Science

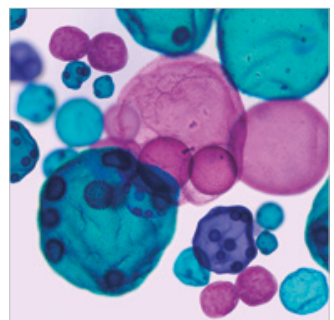

International Journal of Microbiology
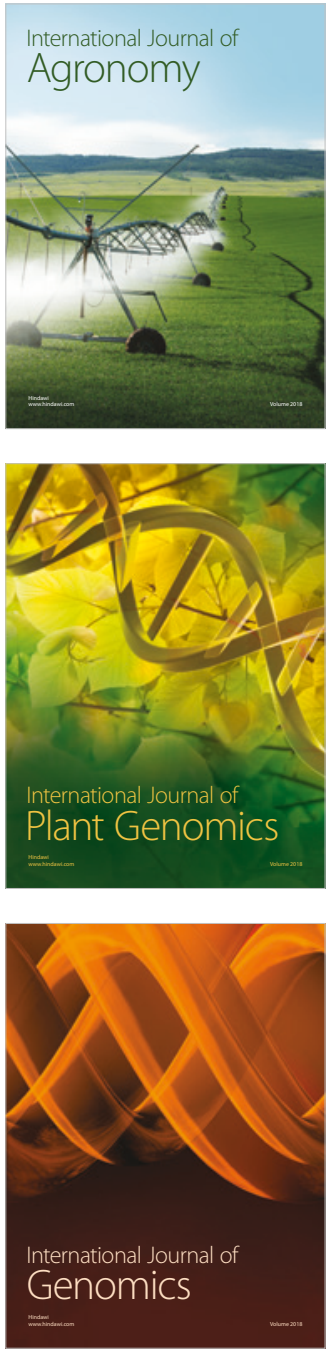

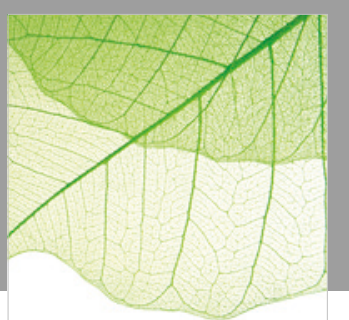

Journal of Botany
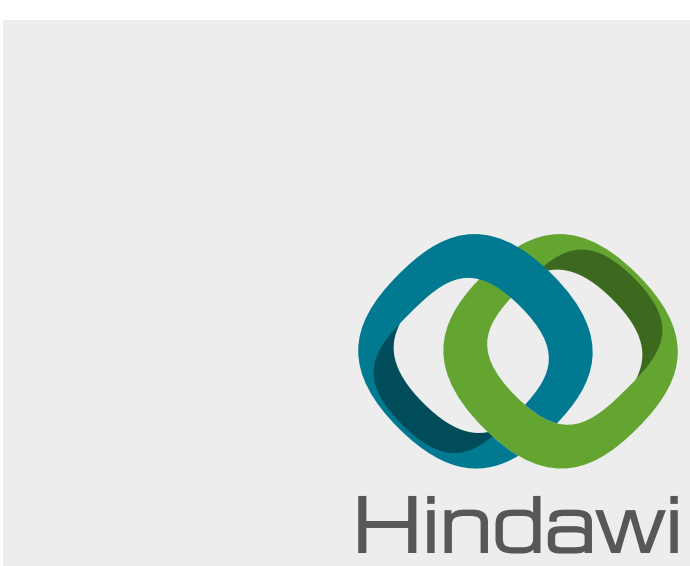

Submit your manuscripts at

www.hindawi.com
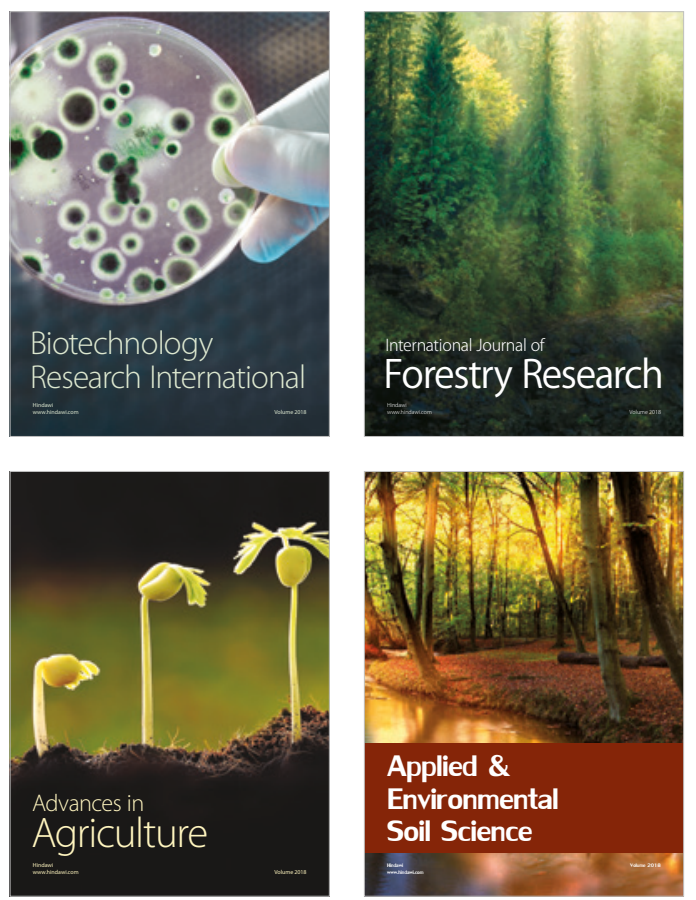

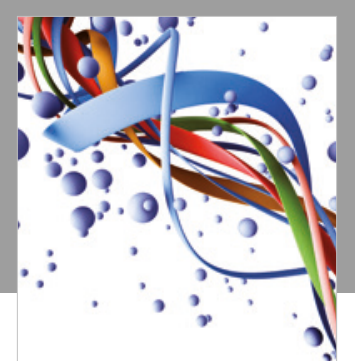

Scientifica

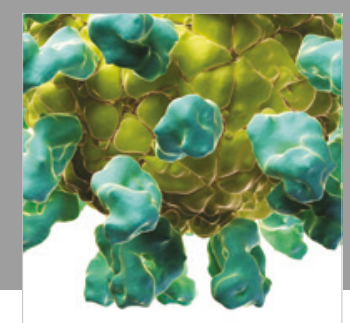

Veterinary Medicine International

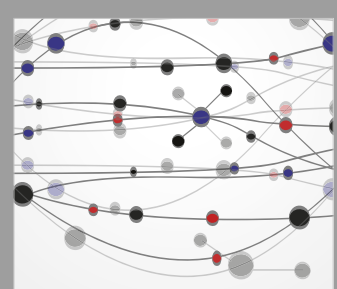

The Scientific World Journal
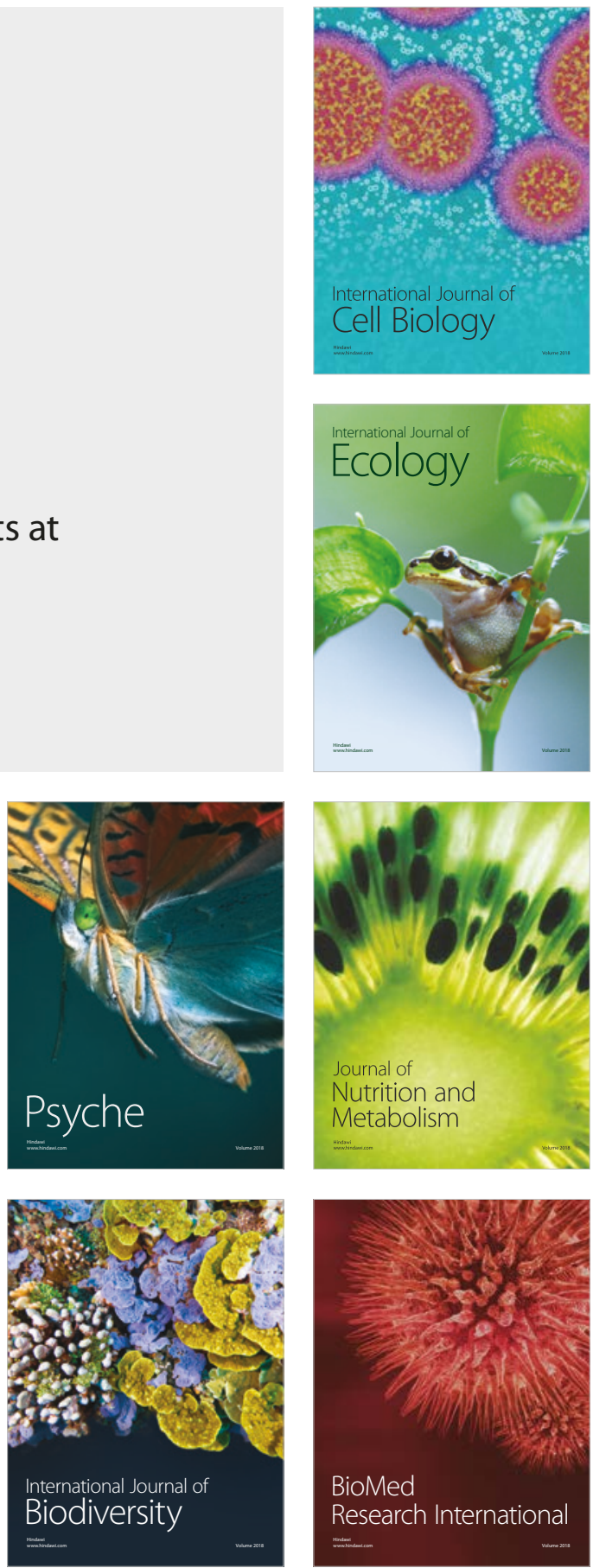